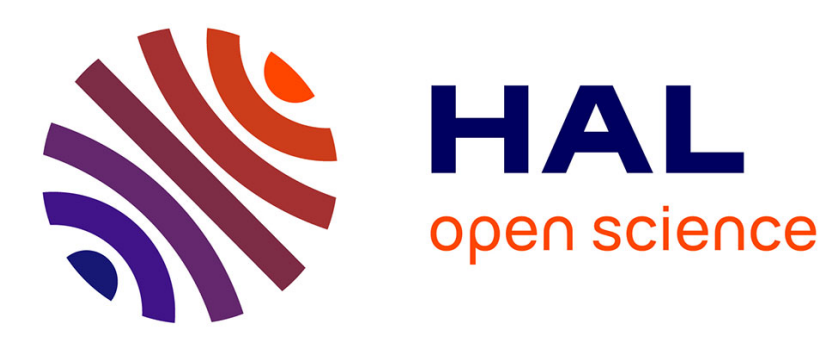

\title{
Unexpected deposit flows, off-balance sheet funding liquidity risk and bank loan production
}

\author{
Thierno Barry, Alassane Diabaté, Amine Tarazi
}

\section{To cite this version:}

Thierno Barry, Alassane Diabaté, Amine Tarazi. Unexpected deposit flows, off-balance sheet funding liquidity risk and bank loan production. 2020. hal-02516724

\section{HAL Id: hal-02516724 \\ https://hal-unilim.archives-ouvertes.fr/hal-02516724}

Preprint submitted on 24 Mar 2020

HAL is a multi-disciplinary open access archive for the deposit and dissemination of scientific research documents, whether they are published or not. The documents may come from teaching and research institutions in France or abroad, or from public or private research centers.
L'archive ouverte pluridisciplinaire HAL, est destinée au dépôt et à la diffusion de documents scientifiques de niveau recherche, publiés ou non, émanant des établissements d'enseignement et de recherche français ou étrangers, des laboratoires publics ou privés. 


\title{
Unexpected deposit flows, off-balance sheet funding liquidity risk and bank loan production
}

\author{
Thierno Amadou Barry ${ }^{*}$, Alassane Diabaté ${ }^{1 *}$, Amine Tarazi, ${ }^{* * *}$ \\ * Université de Limoges, LAPE, 5 rue Félix Eboué, 87031 Limoges Cedex, France \\ ** Institut Universitaire de France (IUF), 1 rue Descartes, 75231 Paris Cedex 05, France
}

Very preliminary draft: March 23, 2020

Please do not quote without the permission of the authors

\begin{abstract}
:
In this paper, we use U.S. commercial banks' data to investigate whether the effect of unexpected deposit flows on loan production depends on banks' exposure to off-balance sheet funding liquidity risk. We find that lending is sensitive to deposit shocks at small banks but not at large ones. Furthermore, for small banks, the increase in lending explained by unexpected deposit inflows depends on how much they are exposed to funding liquidity risk stemming from their off-balance sheets, as measured by the level of unused commitments. Small banks more exposed to such funding liquidity risk tend to extend fewer new loans. Our results indicate that unexpected deposit inflows from, for instance, the failure of other banks or market disruptions might not as easily be fueled again to borrowers.
\end{abstract}

JEL Classification: G21, G28

Keywords: unexpected deposit flows, loan production, off-balance sheet funding liquidity risk

\footnotetext{
${ }^{1}$ Corresponding author. Tel: +33 555149251

*Email Address: thierno-amadou.barry@unilim.fr (T. A. Barry), alassane.diabate@,unilim.fr (A. Diabaté), amine.tarazi@unilim.fr (A. Tarazi)
} 


\title{
Unexpected deposit flows, off-balance sheet funding liquidity risk and bank loan production
}

\begin{abstract}
:
In this paper, we use U.S. commercial banks' data to investigate whether the effect of unexpected deposit flows on loan production depends on banks' exposure to off-balance sheet funding liquidity risk. We find that lending is sensitive to deposit shocks at small banks but not at large ones. Furthermore, for small banks, the increase in lending explained by unexpected deposit inflows depends on how much they are exposed to funding liquidity risk stemming from their off-balance sheets, as measured by the level of unused commitments. Small banks more exposed to such funding liquidity risk tend to extend fewer new loans. Our results indicate that unexpected deposit inflows from, for instance, the failure of other banks or market disruptions might not as easily be fueled again to borrowers.
\end{abstract}

JEL Classification: G21, G28

Keywords: unexpected deposit flows, loan production, off-balance sheet funding liquidity risk 


\section{Introduction}

In the aftermath of the global financial crisis of 2007-2009 (GFC), regulators recognized the need to implement liquidity requirements as policy tools in addition to capital adequacy rules. Hence, the Basel Committee on Banking Supervision (BCBS) implemented the Net Stable Funding Ratio (NSFR) which requires banks to soundly manage their liquidity exposure both for their balance sheet and off-balance sheet operations. In this regard, banks are forced to reduce their reliance on market liquidity (e.g. by holding more deposits) to fund their illiquid assets (such as loans) and to cover the potential liquidity risk arising from their off-balance sheet exposures. Banks are therefore expected to account for their exposure to funding liquidity risk stemming from on-and off-balance sheets in the production of their illiquid assets.

In this paper, we analyze the effect of an unexpected flow of deposits on banks' new loan production. Specifically, we investigate whether this effect is dependent on banks' off-balance sheet funding liquidity risk. We define the unexpected flow of deposits as the part of deposit flows at banks which is not explained by banks' specific and macroeconomic variables.

As documented by previous studies, banks with higher deposits can play a crucial role in the financing of the real economy. This is because deposits are at the heart of bank lending and liquidity creation. For instance, Acharya and Naqvi (2012) show that banks that experience large amounts of deposit inflows, have incentives to lower lending standards in order to increase loan production. Brei et al. (2013) document that banks with a lower reliance on market funding, measured by a higher share of deposits, tend to supply more loans. Cornett et al. (2011) also show that during the GFC, banks that relied more on core deposits continued to lend more than other banks.

Banks also provide liquidity to their customers under the form of credit lines. However, the option offered to such customers to withdraw funds when needed from existing credit lines generates a funding liquidity risk at banks which may limit banks' incentives to extend new loans. For example, after the failure of Lehman Brothers in September 2008, firms increased the drawdowns on preexisting credit lines. Thus, banks with higher exposure to funding liquidity risk stemming from loan commitments were less willing to produce new loans during the GFC (Cornett et al., 2011, Ivashina and Scharfstein, 2010). An important issue which has not yet been addressed in the literature is whether and to which extent banks account for their exposure to off-balance sheet funding liquidity risk, in their loan provision, when they experience an unexpected flow of deposits. This issue is of major importance for regulators, policymakers and for the financing of the real economy. Better understanding banks' lending 
behavior is crucial for regulators to improve regulatory tools and to maintain a sound banking system.

To conduct our investigation, we use a large sample of U.S. commercial banks covering the 1990Q2-2015Q2 period. Because of their appetite for risk and their more or less easy access to funds to finance their activities, banks' lending behavior can vary according to their size and to their more or less stable environment. Therefore, we account for banks' size and the GFC. Managers of banks holding fewer liquid assets may also care more about their off-balance sheet liquidity risk exposure. To compute our main proxy of unexpected deposit flows, we use the residuals of a model explaining deposit flows at the individual bank level . For robustness considerations we also use alternative measures.

Our findings show that large banks do not respond to an unexpected change in their deposits by adjusting their lending. However, small banks significantly react to such unexpected movements. Large banks might not be influenced by negative deposit shocks because they have easier access to the market than small banks. But whereas small banks significantly increase their loan production when they experience unexpected deposit inflows, large banks do not change their lending policy. Nevertheless, under such circumstances, small banks more exposed to off-balance sheet funding liquidity risk tend to produce fewer loans than those that are less exposed. In other words, the impact of unexpected deposit inflows on loan origination by small banks is negatively associated with the exposure to off-balance sheet funding liquidity risk. This negative relationship is found to be tighter during the GFC and concentrated in the subsample of small banks with fewer holdings of liquid assets.

This paper brings some important insights on the lending behavior of banks. The positive effect we find for small banks of unexpected deposit inflows on new loans extension, is consistent with the theoretical work of Acharya and Naqvi's (2012) according to which the inflow of deposits leads banks' managers to decrease lending standards in order to lend more. This view is also documented by Khan et al. (2017). They bring evidence that banks with lower funding liquidity risk (proxied by a higher ratio of deposits to total assets), especially small ones, take more risk. However, in our study we focus on unexpected deposit flows and banks' new loan production and especially, we show that this loan creation after an inflow of deposits is not uniform. The exposure to off-balance sheet funding liquidity risk matters.

We also complete the results of Cornett et al. (2011) and Ivashina and Scharfstein (2010) who document that banks highly exposed to funding liquidity risk stemming from unused commitments extended less loans during the GFC. Indeed, in our paper, we show that this attitude also holds during normal times and especially for small banks even when they 
experience positive deposit shocks. Overall, our results indicate that unexpected deposit inflows might not as easily be fueled again to borrowers.

The remainder of the paper is organized as follow. In section 2, we present our data and the methodology. In section 3, we present the results. Section 4 discusses further issues. In section 5 , we provide the robustness checks and section 6 concludes.

\section{Data and Methodology}

\subsection{Presentation of the sample:}

Our dataset consists of an unbalanced panel of quarterly data for U.S. commercial banks from 1990Q2 to 2015Q2. It contains 599,263 bank-quarter observations for 13,757 banks. Bank-quarters with missing information on total assets, total deposits, net loans and unused commitments are excluded. We focus on commercial banks because they are more involved in lending activities. Our data come from two different sources. Macroeconomic data come from the federal reserve bank of St Louis ${ }^{2}$ and bank level data from SNL Financial. Because, banks' lending behavior may be different according to their size, we split the sample in two groups. Following the literature and the classification used by the Uniform Bank Performance Report (UBPR), banks are considered to be large, if their total assets are higher than $\$ 1$ billion and small banks are those with total assets lower or equal to $\$ 1$ billion. Hence, our sample contains 570,611 bank-quarter observations for small banks and 28,652 bank-quarter observations for large ones. To deal with the issue of possible outliers, we winsorize our variables at the $2^{\text {nd }}$ and $98^{\text {th }}$ percentiles of the sample distributions.

\subsection{Definition of variables:}

\subsubsection{Dependent variable:}

The aim of this paper is to study the effect of an unexpected flow of deposits on new loan extension. Banks' lending can increase not only because of the production of new loans but also because of the drawdowns of preexisting loan commitments. Therefore, we capture the production of new loans by following Berger et al. (2017), Kim and Sohn (2017) and Cornett et al. (2011) and use the growth rate of the sum (total net loans plus unused commitments) as the dependent variable. As highlighted by Cornett et al. (2011), loan commitment drawdowns

\footnotetext{
${ }^{2}$ See http://research.stlouisfed.org/
} 
do not affect this measure of loan supply because the drawdowns of unused commitments increase loans and decrease undrawn commitments by the same amount. Hence, an increase in our dependent variable shows the production of new loans and underlines banks' managers willingness to extend loans.

\subsubsection{Off-balance sheet funding liquidity risk:}

We follow Cornett et al. (2011) and measure the exposure to off-balance sheet funding liquidity risk by considering the level of unused commitments. We define the variable OBFLR as the ratio of total unused commitments over the sum of total unused commitments plus total assets. Higher levels of this ratio capture higher exposures to off-balance sheet funding liquidity risk.

\subsubsection{Unexpected deposit flows:}

To measure unexpected deposit flows, we follow the procedure used by Karolyi et al. (2018) to capture unexpected bank flows. According to banks' size, we first regress banks' deposit flows on variables known to affect them in prior works (see e.g. Chen et al., 2019; Acharya and Mora, 2015; Nys et al., 2015; Finger and Hesse, 2009; etc.) through the following model:

$$
\Delta \operatorname{dep}_{i, t}=\beta X_{i, t-1}+\delta_{i}+\phi_{t}+\eta_{i, t}
$$

Where $\Delta \operatorname{dep}_{i, t}$ is deposit flows measured as the changes in bank $i$ 's deposits at $t$, normalized by lagged total assets; $X_{i, t-1}$ is a vector of variables likely to explain deposit flows. It contains the natural logarithm of total assets to account for bank size, cost of interest bearing deposits to account for the cost of deposits, equity capital over total assets to account for capitalization, non-performing loans to total loans to account for credit risk, return on equity to account for profitability, the share of loans secured by real estate in the loan portfolio to account for real estate exposure, OBFLR for liquidity demand and a dummy for mergers and acquisitions. $\delta_{i}$ serves to capture bank i's individual fixed effect to account for time invariant differences in business models and $\phi_{t}$ captures time fixed effects included to account for macroeconomic factors $^{3}$ that influence the flow of deposits. We cluster standard errors at the bank level and use fixed effect estimators. We then extract from the residual $\eta_{i, t}$ from the model which

\footnotetext{
${ }^{3}$ For robustness tests, we use as macroeconomic factors the TED spread and change in the consumer price index instead of time fixed effects.
} 
corresponds to unexpected deposit flows at bank $i$ in time $t$. This is the component of deposit flows at banks which is not explained by banks characteristics and time effects (or macroeconomic variables).

For robustness, we also measure unexpected deposit flows by considering the method used by Soedarmono et al. (2017) and Foos et al. (2010) to compute abnormal loan growth that they define as the gap between an individual bank's loan growth and the median loan growth of banks in the same year and country. Thus, specifically, instead of using the residuals of a deposit growth model or a deposit change model, we consider deviations from banking industry averages or medians.

\subsubsection{Descriptive statistics:}

The definition and general descriptive statistics of our variables are presented in table 1A. On average over our investigation period, the growth rate of the sum of total net loans and unused commitments is $1.60 \%$. On average, the exposure to off-balance sheet funding liquidity risk is $12.07 \%$ and $1.31 \%$ of bank loans are non-performing loans The average return on equity is $10.33 \%$ and average equity over total assets ratio is $10.32 \%$. The exposure of sample banks to real estate loans is on average $57.67 \%$.

Table 1B presents mean-difference t-tests for our main variables during normal and crisis times and according to bank size. Considering small banks, on average, they produced more loans in normal times. In such times, the mean of the growth rate of the sum of total net loans plus unused commitments is $1.62 \%$ against $1.30 \%$ during the crisis. On average, their exposure to off-balance sheet funding liquidity risk was more important during the crisis period (14.96\%) than during normal times (11.55\%). Large banks also produced more loans in normal times $(1.65 \%)$ than during the crisis period (1.18\%) on average. However, conversely to small banks, they were less exposed to off-balance sheet funding liquidity risk during the crisis period $(10.16 \%)$ than in normal times (11.40\%). Appendix A displays the pairwise correlation matrix between our variables and does not reveal major multicollinearity issues.

[insert table $1 \mathrm{~A} \&$ table $1 \mathrm{~B}]$ 


\subsection{Empirical specifications:}

We use a dynamic panel regression model as most studies on bank lending (See e.g. Kim and Sohn. 2017; Brei et al 2013; Drehmann and Gambacorta. 2012 and others), We first model the production of new loans as a function of unexpected deposit flows, banks' exposure to offbalance sheet funding liquidity risk and other bank-specific variables. To examine whether and to which extent the effect of unexpected deposit flows is conditional to banks' exposure to offbalance sheet funding liquidity risk, we then construct our baseline model by adding the interaction of unexpected deposit flows with banks' exposure to off-balance sheet funding liquidity risk. The specifications are given by:

$$
\begin{aligned}
\Delta \operatorname{loan}_{i, t}=\gamma_{i} & +\theta_{t}+\alpha_{1} \Delta \operatorname{loan}_{i, t-1}+\alpha_{2} U D F_{i, t-1}+\alpha_{3} O B F L R_{i, t-1} \\
& +\alpha Z_{i, t-1}+\rho_{i, t} \\
\operatorname{sloan}_{i, t}=\gamma_{i} & +\theta_{t}+\omega_{1} \Delta \operatorname{loan}_{i, t-1}+\omega_{2} U D F_{i, t-1}+\omega_{3} O B F L R_{i, t-1} \\
& +\omega_{4} U D F_{i, t-1} * O B F L R_{i, t-1}+\omega Z_{i, t-1}+\mu_{i, t}
\end{aligned}
$$

Where $\Delta \operatorname{loan}_{i, t}$ is the growth rate of the sum of total net loans and unused commitments of bank $i$ at time $t ; \gamma_{i}$ captures bank $i$ 's individual fixed effect; $\theta_{t}$ is a time fixed effect ${ }^{4} ; U D F_{i, t-1}$ stands for the unexpected deposit flows for bank $i$ at time $t-1 ; O B F L R_{i, t-1}$ is the exposure to off-balance sheet funding liquidity risk; $Z_{i, t-1}$ is a vector of control variables known to explain bank lending. It contains the natural logarithm of total assets to account for bank size, equity capital over total assets to account for banks' capitalization, non-performing loans to total loans to account for credit risk, return on equity to account for profitability, the share of loans secured by real estate in loan portfolio to account for real estate exposure and a dummy for mergers and acquisitions. Variables on the right-hand side are lagged one period to mitigate possible endogeneity issues.

$\alpha_{2}$ provides the effect of unexpected deposit flows on new loan extension and $\omega_{2}$ captures this effect for banks less exposed to off-balance sheet funding liquidity risk. These coefficients

\footnotetext{
${ }^{4}$ We remove time dummies and include the growth rate of real GDP per capita in robustness checks to control for loan demand.
} 
are expected to be positive. Unexpected deposit flows should positively impact banks loan extension because deposits are one of the main financing sources of commercial banks.

$\alpha_{3}$ captures the effect on loan extension of the exposure to off-balance sheet funding liquidity risk. $\omega_{3}$ captures this effect for banks that are not subject to unexpected deposit flows. $\alpha_{3}$ and $\omega_{3}$ are expected to be negative because banks' exposure to off-balance sheet funding liquidity risk should limit the extension of new loans. Indeed, the managers of banks with greater unused commitments are aware of the fact that they may need funds to satisfy greater liquidity demand from outstanding commitments.

Thus, intuitively, the impact of unexpected deposit flows on lending should be stronger for banks less exposed to off-balance sheet funding liquidity risk. Therefore, this effect should be negatively associated with the level of bank exposure to funding liquidity risk stemming from the off-balance sheet. Our main coefficient of interest $\omega_{4}$ should be negative and significant.

\subsection{Estimation method:}

We use a dynamic panel regression model. For such models, Blundell and Bond (1998), Arellano and Bond (1991) and Anderson and Hsiao (1982) suggest General Method of Moment (GMM) estimation procedures because the presence of the lagged dependent variable generates correlation between the regressor and the error term which leads to a bias in the coefficient estimates (Nickell, 1981), which will be inconsistent (Shim, 2012). However, in the case of large time dimension, the dynamic panel bias becomes insignificant (Roodman, 2006, 2009) and as argued by kiviet (1995), the standard estimation procedures are asymptotically valid. In addition, Loutskina (2011) suggests that the bias becomes problematic when $\mathrm{T}$ is below 15 time periods and Judson and Owen (1999) indicate that fixed effects estimators perform better than GMM estimators when $\mathrm{T}$ is beyond 30 . Hence, because the time dimension in our investigation is 101 (1990Q2-2015Q2), we use fixed effect estimations after performing Hausman tests. Several other papers in the literature also use fixed effect estimators because of a large time dimension (e.g. Kim and Sohn, 2017 and Berrospide and Edge, 2010). However, for robustness, we also estimate our equations without the lagged dependent variable.

\section{Results:}

In this paper, we investigate whether the impact of unexpected deposit flows on loan origination differs depending upon the level of bank exposure to off-balance sheet funding 
liquidity risk. We split our sample in two groups according to bank size. We cluster standard errors at the bank level. Table 2 gives the results of our estimations.

Columns (1) and (4) give the results of equation (1). The results of equation (2) are displayed in Columns (2) and (5). These results show that $\alpha_{2}$ is not significant for large banks but it is positive and significant at $1 \%$ for small banks. Hence, unexpected deposit inflows (outflows) lead small banks, not large ones, to extend (cut) new loans. $\alpha_{3}$ is negative and significant at $5 \%$ for large banks and at $1 \%$ for small banks. Therefore, being exposed to funding liquidity risk stemming from off-balance sheet leads commercial banks to produce fewer loans.

The results of our baseline model are presented in Columns (3) and (6). We find that $\omega_{2}$ is not significant for large banks. Thus, unexpected deposit flows have no effect on new loan production of large banks less exposed to off-balance sheet funding liquidity risk. $\omega_{2}$ is however found to be positive and significant at $1 \%$ for small banks. Under the influence of unexpected deposit inflows (outflows), less exposed small banks increase (decrease) their new loan production. We observe that a one standard deviation increase in our measure of unexpected deposit flows, increases their new loan production by $17.42 \%$ of its mean (from $1.55 \%$ to $1.82 \%)$.

We find that $\omega_{3}$ is negative and significant at $5 \%$ for large banks and negative and significant at $1 \%$ for small banks. Thus, being exposed to off-balance sheet funding liquidity risk leads commercial banks, small or large, and less subject to unexpected changes in their deposits, to supply less loans. For large banks not subject to unexpected changes in their deposits, we observe that a one standard deviation increase in their off-balance sheet funding liquidity risk exposure is associated with a decline in their new loan production by $37.66 \%$ of its mean (from $1.54 \%$ to $0.96 \%$ ). Concerning small banks not subject to deposit shocks, the results show that a one standard deviation increase in their off-balance sheet funding liquidity risk exposure leads to a decline in their new loan production by $83.87 \%$ of its mean (from $1.55 \%$ to $0.25 \%$ ). These changes are economically large.

Our main coefficient of interest $\omega_{4}$ is found to be not significant for large banks. Therefore, the effect of unexpected deposit flows on lending is not sensitive to large banks' exposure to off-balance sheet funding liquidity risk. However, $\omega_{4}$ is significant and negative at $1 \%$ for small banks. This finding confirms our conjecture and indicates that for small banks, the effect of unexpected deposit flows on their loan production, is negatively associated with their exposure to off-balance sheet funding liquidity risk. Small banks more exposed to that type of funding liquidity risk have a lower growth of new loans when they experience an unexpected inflow of deposits compared to less exposed small banks. Similarly, less exposed small banks cut lending 
to a lesser extent than more exposed small banks when they are subject to an unexpected outflow of deposits.

Overall, unexpected deposit inflows (outflows) lead only small U.S. commercial banks to increase (decrease) their new loan production. This result is consistent with empirical studies documenting the positive effect of deposits on bank lending. It is also in line with the theoretical prediction of Acharya and Naqvi (2012) indicating an increase in loan production following an inflow of deposits. However, our results show such a behavior only holds for small banks. Moreover, we show that small banks appear to be cautious as they jointly manage their deposits and off-balance sheet funding liquidity risk exposure. Their willingness to make new loans and to offer loan commitments when they benefit from positive deposit shocks is tempered by the fear of withdrawal risk. Nevertheless, when they are less exposed to off-balance sheet funding liquidity risk, their confidence is boosted when they experience unexpected deposit growth which leads them to increase their lending production. As to large banks, unexpected changes in their deposits do not significantly influence their lending production regardless of the degree of their exposure to off-balance sheet funding liquidity risk. This is probably because, conversely to small ones, they have easier access to alternative funds to finance their lending.

[insert table 2]

\section{Further issues:}

\subsection{Crisis period:}

Banks' lending behavior can be different during crisis periods. We therefore conduct our investigation by considering the GFC. We consider the following specification:

$$
\begin{aligned}
& \Delta \operatorname{loan}_{i, t}=\psi_{i}+\xi_{t}+\varphi_{1} \Delta \operatorname{loan}_{i, t-1}+\varphi_{2} U D F_{i, t-1}+\varphi_{3} U D F_{i, t-1} * G F C_{t} \\
& +\varphi_{4} O B F L R_{i, t-1}+\varphi_{5} O B F L R_{i, t-1} * G F C_{t} \\
& +\varphi_{6} U D F_{i, t-1} * O B F L R_{i, t-1}+\varphi_{7} U D F_{i, t-1} * O B F L R_{i, t-1} * G F C_{t} \\
& +\varphi Z_{i, t-1}+\varepsilon_{i, t}
\end{aligned}
$$

Where $G F C_{t}$ is a dummy variable equal to 1 during the 2007Q3-2009Q2 period. Estimation results are presented in table 3. Our findings also hold during the GFC. During that period, unexpected changes in deposits did not influence large banks in their lending decisions and the impact of such changes did not depend on large banks' exposure to off-balance sheet funding 
liquidity risk. However, for small banks, the results show that during the GFC, unexpected changes in their deposits positively impacted their lending production and this impact was negatively related to their off-balance sheet liquidity risk exposure. More importantly, we find $\varphi_{7}$ to be smaller than $\varphi_{6}$ indicating that the negative relationship was stronger during the GFC. This is probably because loan commitments are callable at the borrower's option and the borrower will mostly exercise the option when markets are less likely to meet his needs. During the GFC, markets could not easily provide funds to bank borrowers. Thus, the demand for funds at banks was more important which made them more reluctant to generate loans even when they experienced positive deposit shocks. In addition, as shown by our data, small banks were more exposed to off-balance sheet funding liquidity risk during the GFC than during normal times.

[insert table 3]

4.2.Does banks' on-balance sheet liquidity level matter?

In this sub-section, we conduct our investigation by considering banks' on-balance-sheet liquidity level. Indeed, when banks experience an unexpected outflow (inflow) of deposits, less liquid banks might be more (less) willing to cut (increase) their loans than their peers holding more liquid assets. The latter might also less consider, in their loan production, their exposure to funding liquidity risk stemming from off-balance sheet than less liquid banks. Therefore, we split our sample to isolate less liquid banks from more liquid banks. Specifically, we proxy onbalance sheet liquidity by the ratio of total liquid assets to total assets and we assume that banks that are above the $75^{\text {th }}$ percentile of this ratio, are relatively more liquid banks.

Table 4 presents the results of our estimations. They are globally similar to our main results for large banks. Concerning small banks, $\omega_{2}$ is positive and significant at $1 \%$ in all estimations. Regardless of high liquid they are on the balance sheet, small banks less exposed to off-balance sheet funding liquidity risk increase (decrease) their lending production after experiencing an unexpected inflow (outflow) of deposits. Most interestingly, $\omega_{4}$ is negative and significant for less liquid small banks and non-significant for more liquid ones. Such a result indicates that while less liquid small banks account for their exposure to off-balance sheet funding liquidity risk to produce or to cut loans when they experience an unexpected flow of deposits, more liquid banks do not. For such banks, the effect of unexpected flow of deposits is not sensitive to their exposure to off-balance sheet funding liquidity risk. This is because, contrary to less 
liquid banks, they have enough liquidity to satisfy liquidity demand. All in all, small banks holding less liquid assets and more exposed to off-balance sheet liquidity risk produce fewer loans than less liquid and less exposed peers.

[insert table 4]

\section{Robustness tests:}

We perform several tests to check whether our results are robust. Firstly, we use fixed effect estimators because the time dimension in our investigation is large. As discussed above, it is argued that the presence of the lagged dependent variable may lead to inconsistent coefficients if General Method of Moment (GMM) estimation procedures are not used. Thus, to check the robustness of our results, we drop the lagged dependent variable and estimate our equations. We find similar results (see appendix B).

Secondly, we use alternative methodologies to compute the unexpected flow of deposits. We adapt the method used by Soedarmono et al. (2017) and Foos et al. (2010) to compute abnormal loan growth ${ }^{5}$. Firstly, we compare the deposit growth at each bank level to the aggregate deposit growth by also taking bank size into consideration. Thus, for small (large) banks, the unexpected flow of deposits is the difference between the deposit growth of the small (large) bank $i$ and the aggregate deposit growth of small (large) banks. Secondly, we use the difference between each bank's deposit growth and the median deposit growth for each quarter. Using these alternative methodologies, our main results remain unchanged (see appendix C).

We also use core deposits as an alternative variable to total deposits. Banks' core deposits are the most stable deposits and constitute the most stable source of funds for loans. Hence, banks that hold a large portion of core deposits may have more incentives to lend. Our estimations with this type of deposits give similar results with our baseline models (see appendix D).

In addition, we limit our sample to banks that are strongly focused on intermediation activities that we name "traditional banks". These banks are heavily focused on deposits and loans. We select banks with a ratio of total deposits to total assets and a ratio of total loans to

\footnotetext{
${ }^{5}$ In their studies, they estimate abnormal loan growth by computing the difference between bank $i$ 's loan growth and the aggregate loan growth in the banking system. They also make the difference between an individual bank's loan growth and the median loan growth of banks from the same country and year.
} 
total assets above $30 \%$. Considering this restricted sample of "traditional banks", our findings remain unchanged (see appendix E).

We capture the unexpected flow of deposits by including time fixed effects in equation (1) to account for macroeconomic effects. As a robustness check, we replace time dummies by macroeconomic factors that explain the flow of deposits, namely the TED spread and the change in the consumer price index (CPI). In our baseline model, we also analyze the conditional impact of an unexpected flow of deposits on loan production by using time fixed effects. We replace the time dummies by the growth rate of real GDP per capita. GDP allows to control for loan demand effects (De Haas et al., 2015; Carlson et al., 2013). Using these macroeconomic variables, our results remain unchanged (see appendix $\mathrm{F}$, table $1 \mathrm{~F}$ and table $2 \mathrm{~F})$.

In this study, because mergers and acquisitions can disturb our analysis, we control for their effect by including a dummy variable. Instead, we also exclude bank-quarter observations with quarterly growth of total assets higher than $10 \%$. We find similar results (see appendix G).

Finally, using the sub-sample of small banks, we remove the lag dependent variable from equation $(2)^{6}$ and compute the effect of an unexpected flow of deposits on lending at different levels of the exposure to off-balance sheet funding liquidity risk. The results are presented in appendix $\mathrm{H}$ and they are in line with our findings. The coefficient of the unexpected flow of deposits decreases gradually as the exposure to off-balance sheet funding liquidity risk increases.

\section{Conclusion}

Using U.S. commercial banks data, we investigate whether the impact of an unexpected flow of deposits on loan origination depends on the degree of banks' off-balance sheet funding liquidity risk exposure. We account for bank size, the global financial crisis of 2007-2009 (GFC) and bank liquidity on the asset side of the balance sheet. The results show that large banks are not sensitive to deposit shocks regardless of their on-balance or off-balance sheet liquidity positions. However, small banks are sensitive to such shocks, unexpected deposit flows being positively associated with lending. The impact on lending is nevertheless negatively associated with their exposure to off-balance sheet funding liquidity risk and the relationship is even stronger during the GFC. Such a relationship is mostly relevant for small

\footnotetext{
${ }^{6}$ We use the command "margins, dydx()" in STATA 14. This command works with models without lagged dependent variables.
} 
banks holding relatively less liquid assets on their balance sheet. Such banks account for their exposure to liquidity demand when producing new loans driven by an unexpected increase in deposits. Our results have policy implications and indicate that unexpected deposit inflows due, for example, to the failure of other banks or market disruptions may not be as easily fueled to borrowers. 


\section{References}

Acharya, V., V., Mora, N., 2015. A crisis of banks as liquidity providers. Journal of Finance, 70 (1), 1-43.

Acharya, V., V., Naqvi, H., 2012. The seeds of a crisis: a theory of bank liquidity and risk taking over the business cycle. Journal Financial Economics 106, 349-366.

Anderson, T., W., Hsiao, C., 1982. Formulation and estimation of dynamic models using panel data. Journal of Econometrics 18 (1), 47-82.

Arellano, M., Bond, S., 1991. Some tests of specification for panel data: Monte Carlo evidence and an application to employment equations. Review of Economic Studies 58, 277 297.

Berger, A., N., Black, L., K., Bouwman, C., H., S., Dlugosz, J., 2017. Bank loan supply responses to Federal Reserve emergency liquidity facilities. Journal of Financial Intermediation 32, 1-15.

Berrospide, J., M., Edge, R., M., 2010. The effects of bank capital on lending: What do we know, and what does it mean? International Journal of Central Banking, 5-54.

Brei, M., Gambacorta, L., von Peter, G., 2013. Rescue packages and bank lending. Journal of Banking \& Finance 37, 490-505.

Carlson, M., Shan, H., Warusawitharana, M., 2013. Capital ratios and bank lending: A matched bank approach. Journal of Financial Intermediation 22(4), 663-687.

Chen, Q., Goldstein, I., Huang, Z., Vashishtha, R., 2019. Bank transparency and deposit flows. Available at SSRN https://ssrn.com/abstract=3212873.

Cornett, M., M., McNutt, J., J., Strahan, P., E., Tehranian, H., 2011. Liquidity risk management and credit supply in the financial crisis. Journal of Financial Economics 101 (2), 297-312.

De Haas, R., Korniyenko, Y., Pivovarsky, A., Tsankova, T., 2015. Taming the herd? Foreign banks, the Vienna Initiative and crisis transmission. Journal of Financial Intermediation 24 (3), 325-355.

Drehmann, M., Gambacorta, L., 2011. The Effects of Countercyclical Capital Buffers on Bank Lending. Applied Economic Letters 19(7), 603-608.

Finger, H., Hesse, H., 2009. Lebanon-determinants of commercial bank deposits in a regional financial center. IMF Working Paper WP/09/195.

Foos, D., Norden, L., Weber, M., 2010. Loan growth and riskiness of banks. Journal of Banking \& Finance 34, 2929-2940. 
Ivashina, V., Scharfstein, D., 2008. Bank lending during the financial crisis of 2008. Journal of Financial Economics 97(3), 319-338.

Judson, R., A., Owen, A., L., 1999. Estimating dynamic panel data models: a guide for macroeconomists. Economics Letters 65 (1), 9-15.

Karolyi, G., A., Sedunov, J., Taboada, A., G., 2018. Cross-border bank flows and systemic risk. Available at SSRN https://ssrn.com/abstract=2938544.

Keeley, M., C., 1990. Deposit insurance, risk, and market power in banking. American Economic Review 80, 1183-1200.

Khan, M., S., Scheule, H., Wu, E., 2017. Funding liquidity and bank risk taking. Journal of Banking \& Finance 82, 203-216.

Kim, D., Sohn, W., 2017. The effect of bank capital on lending: Does liquidity matter? Journal of Banking \& Finance 77, 95-107.

Kiviet, J., F., 1995. On Bias, Inconsistency, and Efficiency of Various Estimators in Dynamic Panel Data Models. Journal of Econometrics 68(1), 53-78.

Loutskina, E., 2011. The role of securitization in bank liquidity and funding management. Journal of Financial Economics 100(3), 98-110.

Mise, E., Kim, T., H., Newbold, P., 2005. On suboptimality of the Hodrick-Prescott filter at time series endpoints. Journal of Macroeconomics 27, 53-67.

Nickell, S., 1981. Biases in Dynamic Models with Fixed Effects. Econometrica 49, 13991416.

Nys, E., Tarazi, A., Trinugroho, I., 2015. Political connections, bank deposits, and formal deposit insurance. Journal of Financial Stability 19, 83-104.

Roodman, D., 2006. How to do xtabond2: An introduction to difference and system GMM in Stata. Center for Global Development working paper number 103.

Roodman, D., 2009. How to do xtabond2: An introduction to difference and system GMM in Stata. Stata Journal 9, 86-136.

Shim, J., 2012. Bank capital buffer and portfolio risk: the influence of business cycle and revenue diversification. Journal of Banking and Finance 37 (3), 761-772.

Soedarmono, W., Sitorus, D., Tarazi, A., 2017. Abnormal loan growth, credit information sharing and systemic risk in Asian banks. Research in International Business \& Finance 42, $1208-1218$. 
Table 1A: Definition of variables and general descriptive statistics

\begin{tabular}{|c|c|c|c|c|c|c|}
\hline Variable & definitions & Obs & Mean & Std. Dev. & Min & Max \\
\hline$\Delta$ loan & Quarterly growth rate of the sum of net loans and unused commitments & 599,263 & 0.0160 & 0.0444 & -0.0786 & 0.1735 \\
\hline$\Delta$ dep & Changes in total deposits scaled by lagged total assets & 599,263 & 0.0156 & 0.0467 & -0.0735 & 0.1859 \\
\hline$\Delta$ coredep & Changes in core deposits scaled by lagged total assets & 430,677 & 0.0135 & 0.0447 & -0.0766 & 0.1701 \\
\hline $\mathrm{UDF}^{\mathrm{L}}$ & Unexpected deposit flows for large banks, residual from equation (1). & 16,821 & 0.0000 & 0.0373 & -0.1749 & 0.1916 \\
\hline $\mathrm{UDF}^{\mathrm{S}}$ & Unexpected deposit flows for small banks, residual from equation (1). & 372,085 & 0.0000 & 0.0412 & -0.2414 & 0.2601 \\
\hline $\mathrm{UDF}^{\mathrm{DL}}$ & $\begin{array}{l}\text { Unexpected deposit flows for large banks, the difference between large bank } i \text { 's deposit growth and the growth } \\
\text { of the aggregate deposit of large banks. }\end{array}$ & 27,827 & 0.0080 & 0.0541 & -0.1175 & 0.3119 \\
\hline $\mathrm{UDF}^{\mathrm{DS}}$ & $\begin{array}{l}\text { Unexpected deposit flows for small banks, the difference between small bank } i \text { 's deposit growth and the growth } \\
\text { of the aggregate deposit of small banks. }\end{array}$ & 570,353 & 0.0177 & 0.0567 & -0.1195 & 0.2614 \\
\hline $\mathrm{UDF}^{\mathrm{med}}$ & $\begin{array}{l}\text { Unexpected deposit flows, the difference between a bank's deposit growth and the median of deposit growth } \\
\text { between banks for each quarter. }\end{array}$ & 599,263 & 0.0089 & 0.0562 & -0.1293 & 0.2453 \\
\hline $\mathrm{UDF}^{\mathrm{corL}}$ & Unexpected core deposit flows for large banks, residual from equation (1) & 16,542 & 0.0000 & 0.0326 & -0.1894 & 0.1784 \\
\hline $\mathrm{UDF}^{\mathrm{cor} S}$ & Unexpected core deposit flows for small banks, residual from equation (1) & 368,204 & 0.0000 & 0.0400 & -0.2077 & 0.2349 \\
\hline OBFLR & The exposure to off-balance sheet funding liquidity risk & 599,263 & 0.1207 & 0.1688 & 0.0000 & 0.7909 \\
\hline size & The natural logarithm of total assets & 599,263 & 18.3448 & 1.3571 & 11.6351 & 28.3730 \\
\hline leverage & Equity to total assets ratio & 599,263 & 0.1032 & 0.0371 & 0.0553 & 0.2702 \\
\hline
\end{tabular}

(continued) 
Table 1 (continued)

\begin{tabular}{|c|c|c|c|c|c|c|}
\hline Variable & definitions & Obs & Mean & Std. Dev. & Min & Max \\
\hline NPL & Non-performing loans over total loans & 558,130 & 0.0131 & 0.0191 & 0.0000 & 0.0928 \\
\hline CIBD & Cost of interest-bearing deposits & 596,860 & 0.0361 & 0.0172 & 0.0036 & 0.0708 \\
\hline $\mathrm{M} \& \mathrm{~A}$ & $\begin{array}{l}\text { A dummy variable for mergers and acquisitions. It is equal to one if the asset growth rate is lower than } 10 \% \\
\text { during the quarter and zero otherwise }\end{array}$ & 599,263 & 0.9350 & 0.2466 & 0.0000 & 1.0000 \\
\hline REL & Real estate exposure defined as the share of loans secured by real estate in loan portfolio. & 433,151 & 0.5767 & 0.2054 & 0.0881 & 0.9457 \\
\hline ROE & Return on equity. & 432,985 & 0.1033 & 0.0974 & -0.2638 & 0.3059 \\
\hline INF & Change in consumer price index & 599,263 & 1.0993 & 0.8807 & -5.0123 & 3.3233 \\
\hline rgdpc & The growth rate of GDP per capita & 599,263 & 0.0036 & 0.0061 & -0.0234 & 0.0164 \\
\hline TED spread & The difference between the three-month LIBOR and the three-month T-bill interest rates & 599,263 & 0.0053 & 0.0033 & 0.0015 & 0.0245 \\
\hline
\end{tabular}

Table 1B: T-test of the difference of means

\begin{tabular}{clccc}
\hline Types of banks & variables & Normal time & Crisis time & p-value \\
\hline \multirow{3}{*}{ Small banks } & Sloan & $1.62 \%$ & $1.30 \%$ & 0.00 \\
& UDF & $0 \%$ & $0 \%$ & 1.00 \\
& OBFLR & $11.96 \%$ & $14.55 \%$ & 0.00 \\
\hline \multirow{2}{*}{ Larges banks } & Uloan & $1.65 \%$ & $1.18 \%$ & 0.00 \\
& UDF & $0 \%$ & $0 \%$ & 1.00 \\
& OBFLR & $11.40 \%$ & $10.16 \%$ & 0.00 \\
\hline
\end{tabular}


Table 2: Effect of unexpected deposit flows on banks' new loan origination

This table highlights the conditional impact of unexpected deposit flows on banks' new loan origination. UDF is the unexpected deposit flows. $\Delta$ dep is deposit flows. $\Delta$ loan is the quarterly growth rate of the sum of net loans plus unused commitments. OBFLR is the exposure to off-balance sheet funding liquidity risk. SIZE is the natural logarithm of total assets. LEVERAGE is equity to total assets ratio. NPL is non-performing loans over total loans. CIBD is the cost of interest-bearing deposits. ROE is return on equity. REL is the share of loans secured by real estate in loan portfolio. M\&A is a dummy variable for mergers and acquisitions. It is equal to one if the asset growth rate is lower than $10 \%$ during the quarter and zero otherwise. "large" corresponds to banks with total assets higher than $\$ 1$ billion and "small" corresponds to banks with total assets lower or equal to \$1 billion. Standard errors are in parentheses. *indicate statistical significance at the $10 \%$ level. $*$ *indicate statistical significance at the $5 \%$ level. $* *$ indicate statistical significance at the $1 \%$ level. Right-hand side variables are lagged one quarter.

(1)

\begin{tabular}{|c|c|c|c|c|c|c|}
\hline & & large & & & small & \\
\hline Dependent variable & $\Delta$ dep & $\Delta$ loan & $\Delta$ loan & $\Delta$ dep & $\Delta$ loan & $\Delta$ loan \\
\hline \multirow[t]{2}{*}{ Lag dependent variable } & & $0.0320^{*}$ & $0.0330^{*}$ & & $0.0123^{* * *}$ & $0.0118^{* * *}$ \\
\hline & & $(0.0175)$ & $(0.0175)$ & & $(0.00401)$ & $(0.00401)$ \\
\hline \multirow[t]{2}{*}{$\operatorname{UDF}\left(\omega_{2}, \alpha_{2}\right)$} & & -0.000851 & -0.00776 & & $0.0562^{* * *}$ & $0.0658^{* * *}$ \\
\hline & & $(0.0115)$ & $(0.0129)$ & & $(0.00314)$ & $(0.00360)$ \\
\hline \multirow[t]{2}{*}{$\operatorname{OBFLR}\left(\omega_{3}, \alpha_{3}\right)$} & 0.00904 & $-0.0356^{* *}$ & $-0.0352^{* *}$ & $0.0130^{* * *}$ & $-0.0764^{* * *}$ & $-0.0768^{* * *}$ \\
\hline & $(0.0115)$ & $(0.0176)$ & $(0.0175)$ & $(0.00223)$ & $(0.00394)$ & $(0.00397)$ \\
\hline \multirow[t]{2}{*}{$\operatorname{UDF} * \operatorname{OBFLR}\left(\omega_{4}\right)$} & & & 0.0745 & & & $-0.0693^{* * *}$ \\
\hline & & & $(0.0733)$ & & & $(0.0181)$ \\
\hline \multirow[t]{2}{*}{ SIZE } & $-0.0272^{* * *}$ & $-0.0176^{* * *}$ & $-0.0177^{* * *}$ & $-0.0213^{* * *}$ & $-0.0188^{* * *}$ & $-0.0188^{* * *}$ \\
\hline & $(0.00298)$ & $(0.00190)$ & $(0.00190)$ & $(0.000802)$ & $(0.000762)$ & $(0.000762)$ \\
\hline \multirow[t]{2}{*}{ LEVERAGE } & $0.0844^{* *}$ & 0.0467 & 0.0470 & $0.289^{* * *}$ & $0.157^{* * *}$ & $0.158^{* * *}$ \\
\hline & $(0.0348)$ & $(0.0356)$ & $(0.0358)$ & $(0.0101)$ & $(0.00917)$ & $(0.00916)$ \\
\hline \multirow[t]{2}{*}{ NPL } & $-0.191^{* * *}$ & $-0.359^{* * *}$ & $-0.359^{* * *}$ & $-0.290^{* * *}$ & $-0.333^{* * *}$ & $-0.334^{* * *}$ \\
\hline & $(0.0388)$ & $(0.0550)$ & $(0.0550)$ & $(0.00806)$ & $(0.00848)$ & $(0.00847)$ \\
\hline \multirow[t]{2}{*}{ CIBD } & -0.0166 & & & $0.817^{* * *}$ & & \\
\hline & $(0.0938)$ & & & $(0.0384)$ & & \\
\hline \multirow[t]{2}{*}{ ROE } & $0.0126^{* *}$ & 0.00918 & 0.00915 & $0.00550^{* * *}$ & $0.00399^{* * *}$ & $0.00397^{* * *}$ \\
\hline & $(0.00563)$ & $(0.00570)$ & $(0.00570)$ & $(0.00139)$ & $(0.00139)$ & $(0.00139)$ \\
\hline \multirow[t]{2}{*}{ REL } & $-0.0132^{*}$ & -0.00602 & -0.00624 & 0.000248 & $0.00298^{*}$ & $0.00301^{*}$ \\
\hline & $(0.00725)$ & $(0.00721)$ & $(0.00723)$ & $(0.00163)$ & $(0.00161)$ & $(0.00161)$ \\
\hline \multirow[t]{2}{*}{ M\&A } & 0.000977 & -0.000689 & -0.000687 & $-0.00169^{* *}$ & $-0.00879^{* * *}$ & $-0.00882^{* * *}$ \\
\hline & $(0.00146)$ & $(0.00163)$ & $(0.00163)$ & $(0.000712)$ & $(0.000563)$ & $(0.000563)$ \\
\hline Time fixed effect & yes & yes & yes & yes & yes & yes \\
\hline Banks fixed effect & yes & yes & yes & yes & yes & yes \\
\hline \multirow[t]{2}{*}{ constant } & $0.592^{* * *}$ & $0.397^{* * *}$ & $0.399^{* * *}$ & $0.310^{* * *}$ & $0.346^{* * *}$ & $0.346^{* * *}$ \\
\hline & $(0.0646)$ & $(0.0408)$ & $(0.0407)$ & $(0.0141)$ & $(0.0136)$ & $(0.0137)$ \\
\hline $\mathrm{r} 2$ & 0.186 & 0.204 & 0.204 & 0.206 & 0.186 & 0.186 \\
\hline $\mathrm{N}$ & 16821 & 14951 & 14951 & 372085 & 329951 & 329951 \\
\hline
\end{tabular}


Table 3: GFC and effect of unexpected deposit flows on banks' new loan origination

This table highlights the conditional impact of unexpected deposit flows on banks' new loan origination considering the global financial crisis (GFC). UDF is the unexpected deposit flows. $\Delta$ loan is the quarterly growth rate of the sum of net loans plus unused commitments. OBFLR is the exposure to off-balance sheet funding liquidity risk. GFC is a dummy variable equals to 1 during the global financial crisis. "large" corresponds to banks with total assets higher than $\$ 1$ billion and "small" corresponds to banks with total assets lower or equal to $\$ 1$ billion. Standard errors are in parentheses. ${ }^{*}$ indicate statistical significance at the $10 \%$ level. **indicate statistical significance at the $5 \%$ level. ***indicate statistical significance at the $1 \%$ level. Right-hand side variables are lagged one quarter.

\begin{tabular}{lcc}
\hline Dependent variable & \multicolumn{2}{c}{$\Delta$ loan } \\
\hline & $0.0318^{*}$ & $0.00997^{* *}$ \\
\hline Lag dependent variable & $(0.0175)$ & $(0.00399)$ \\
UDF $\left(\varphi_{2}\right)$ & -0.00604 & $0.0636^{* * *}$ \\
& $(0.0134)$ & $(0.00367)$ \\
UDF* GFC $\left(\varphi_{3}\right)$ & -0.0182 & $0.0924^{* * *}$ \\
& $(0.0359)$ & $(0.0105)$ \\
OBFLR $\left(\varphi_{4}\right)$ & $-0.0320^{*}$ & $-0.0724^{* * *}$ \\
& $(0.0171)$ & $(0.00400)$ \\
OBFLR * GFC $\left(\varphi_{5}\right)$ & $-0.0620^{* * *}$ & $-0.105^{* * *}$ \\
UDF*OBFLR $\left(\varphi_{6}\right)$ & $(0.0190)$ & $(0.00457)$ \\
& 0.0789 & $-0.0624^{* * *}$ \\
UDF*OBFL* GFC $\left(\varphi_{7}\right)$ & $(0.0744)$ & $(0.0192)$ \\
Control variables & 0.0396 & $-0.125^{* * *}$ \\
Time fixed effect & $(0.303)$ & $(0.0480)$ \\
Bank fixed effect & yes & yes \\
constant & yes & yes \\
& yes & yes \\
r2 & $0.402^{* * *}$ & $0.344^{* * *}$ \\
\hline
\end{tabular}


Table 4: Effect of unexpected deposit flows on banks' new loan origination according to banks liquidity level

This table highlights the conditional impact of unexpected deposit flows on banks' new loan origination according to their liquidity level. UDF is the unexpected deposit flows. $\Delta$ loan is the quarterly growth rate of the sum of net loans plus unused commitments. OBFLR is the exposure to off-balance sheet funding liquidity risk. Liquid banks are banks that are above the $75^{\text {th }}$ percentile of the ratio of liquid assets to total assets. Less liquid banks are the ones below the $75^{\text {th }}$ percentile of this ratio. "large" corresponds to banks with total assets higher than $\$ 1$ billion and "small" corresponds to banks with total assets lower or equal to $\$ 1$ billion. Standard errors are in parentheses. $*$ indicate statistical significance at the $10 \%$ level. $* *$ indicate statistical significance at the $5 \%$ level. ***indicate statistical significance at the $1 \%$ level. Right-hand side variables are lagged one quarter.

\begin{tabular}{lcccc}
\hline Dependent variable & \multicolumn{3}{c}{$\Delta$ loan } & \multicolumn{2}{c}{ small } \\
\hline & Less liquid & liquid & Less liquid & liquid \\
\hline Lag dependent variable & 0.0284 & 0.0282 & $0.0153^{* * *}$ & $-0.0443^{* * *}$ \\
& $(0.0208)$ & $(0.0381)$ & $(0.00441)$ & $(0.00747)$ \\
UDF $\left(\omega_{2}\right)$ & -0.00308 & $-0.0316^{*}$ & $0.0644^{* * *}$ & $0.0285^{* * *}$ \\
& $(0.0169)$ & $(0.0183)$ & $(0.00402)$ & $(0.00704)$ \\
OBFLR $\left(\omega_{3}\right)$ & $-0.0426^{* *}$ & -0.0358 & $-0.0836^{* * *}$ & $-0.0866^{* * *}$ \\
& $(0.0174)$ & $(0.0396)$ & $(0.00453)$ & $(0.00703)$ \\
UDF*OBFLR $\left(\omega_{4}\right)$ & 0.0729 & 0.122 & $-0.0599^{* * *}$ & -0.0520 \\
Control variables & $(0.0840)$ & $(0.162)$ & $(0.0207)$ & $(0.0369)$ \\
Time fixed effect & yes & yes & yes & yes \\
Bank fixed effect & yes & yes & yes & yes \\
constant & yes & yes & yes & yes \\
r2 & $0.461^{* * *}$ & 0.221 & $0.397^{* * *}$ & $0.270^{* * *}$
\end{tabular}


Appendix A: correlation matrix

\begin{tabular}{|c|c|c|c|c|c|c|c|c|c|c|c|c|}
\hline & $\Delta$ loan & $\Delta$ dep & $\Delta$ coredep & $\mathrm{UDF}^{\mathrm{L}}$ & $\mathrm{UDF}^{\mathrm{S}}$ & $\mathrm{UDF}^{\text {med }}$ & $\mathrm{UDF}^{\mathrm{DL}}$ & $\mathrm{UDF}^{\mathrm{DS}}$ & $\mathrm{UDF}^{\mathrm{corL}}$ & $\mathrm{UDF}^{\mathrm{corS}}$ & OBFLR & size \\
\hline$\Delta$ loan & 1 & & & & & & & & & & & \\
\hline$\Delta$ dep & 0.2988 & 1 & & & & & & & & & & \\
\hline$\Delta$ coredep & 0.2321 & 0.8629 & 1 & & & & & & & & & \\
\hline $\mathrm{UDF}^{\mathrm{L}}$ & 0.2841 & 0.9025 & 0.6971 & 1 & & & & & & & & \\
\hline $\mathrm{UDF}^{\mathrm{S}}$ & 0.1747 & 0.8909 & 0.7675 & 0 & 1 & & & & & & & \\
\hline $\mathrm{UDF}^{\text {med }}$ & 0.3115 & 0.9779 & 0.8387 & 0.8632 & 0.8958 & 1 & & & & & & \\
\hline $\mathrm{UDF}^{\mathrm{DL}}$ & 0.2687 & 0.8922 & 0.6523 & 0.8319 & 0 & 0.9579 & 1 & & & & & \\
\hline $\mathrm{UDF}^{\mathrm{DS}}$ & 0.3058 & 0.9764 & 0.8394 & 0 & 0.8865 & 0.9894 & 0 & 1 & & & & \\
\hline $\mathrm{UDF}^{\mathrm{corL}}$ & 0.2411 & 0.6919 & 0.9078 & 0.7642 & 0 & 0.6576 & 0.6036 & 0 & 1 & & & \\
\hline $\mathrm{UDF}^{\mathrm{corS}}$ & 0.1427 & 0.7644 & 0.8945 & 0 & 0.8576 & 0.7671 & 0 & 0.7591 & 0 & 1 & & \\
\hline OBFLR & 0.146 & 0.0183 & 0.0084 & -0.0085 & -0.0184 & 0.0216 & -0.0025 & 0.0247 & -0.0078 & -0.016 & 1 & \\
\hline size & -0.0203 & -0.0027 & -0.0035 & 0.0438 & 0.0432 & 0.0061 & -0.1134 & 0.0316 & 0.0395 & 0.038 & -0.1199 & 1 \\
\hline leverage & 0.0731 & 0.0157 & -0.0001 & -0.0299 & -0.1001 & 0.0357 & -0.0015 & 0.0413 & -0.0215 & -0.0872 & 0.0888 & -0.1594 \\
\hline NPL & -0.1784 & -0.1327 & -0.0853 & 0 & -0.0176 & -0.1135 & -0.0589 & -0.1232 & -0.0033 & -0.014 & -0.0361 & 0.0772 \\
\hline REL & 0.0044 & 0.0276 & 0.0284 & 0.0013 & 0.0015 & 0.0292 & 0.0014 & 0.0351 & 0.0021 & 0.0031 & -0.0004 & 0.1774 \\
\hline ROE & 0.029 & -0.0268 & -0.0448 & 0.0233 & 0.0042 & -0.0208 & 0.0389 & -0.0212 & 0.0186 & -0.0012 & -0.0168 & 0.0027 \\
\hline CIBD & 0.0554 & 0.0661 & 0.052 & 0.0291 & 0.015 & 0.0378 & 0.0387 & 0.0179 & 0.0291 & 0.0126 & -0.0582 & -0.2532 \\
\hline rgdpc & 0.0589 & -0.0241 & -0.0195 & 0 & 0 & -0.0077 & 0.0492 & 0.042 & 0 & 0 & 0.0088 & -0.0185 \\
\hline INF & 0.0179 & -0.0079 & -0.0129 & 0 & 0 & 0.0043 & -0.0091 & -0.0194 & 0 & 0 & 0.0028 & -0.0129 \\
\hline TED spread & 0.017 & 0.0597 & 0.0246 & 0 & 0 & 0.022 & 0.0047 & 0.0268 & 0 & 0 & 0.0037 & -0.0385 \\
\hline
\end{tabular}

(continued) 
Appendix A (continued)

\begin{tabular}{lcccccccc}
\hline & leverage & NPL & REL & ROE & CIBD & rgdpc & INF & TED spread \\
\hline leverage & 1 & & & & & & & \\
NPL & -0.0667 & 1 & & & & & & \\
REL & -0.0102 & 0.0503 & 1 & & & & & \\
ROE & -0.0714 & -0.1681 & -0.066 & 1 & & & & \\
CIBD & -0.1352 & -0.1163 & -0.2915 & 0.0627 & 1 & & & \\
rgdpc & 0.0097 & -0.09 & -0.0066 & 0.1101 & -0.1411 & 1 & & \\
INF & -0.0074 & -0.0237 & -0.0132 & 0.0133 & 0.1024 & 0.0796 & 1 \\
TED spread & -0.0003 & -0.0701 & -0.0492 & -0.0631 & 0.3973 & -0.3615 & -0.1323 & 1 \\
\hline
\end{tabular}


Appendix B: Baseline models without lagged dependent variable

This table highlights the conditional impact of unexpected deposit flows on banks' new loan origination using our baseline models without the lagged dependent variable. $\Delta$ loan is the quarterly growth rate of the sum of net loans plus unused commitments. UDF is the unexpected deposit flows. OBFLR is the exposure to off-balance sheet funding liquidity risk. "large" corresponds to banks with total assets higher than $\$ 1$ billion and "small" corresponds to banks with total assets lower or equal to $\$ 1$ billion. Standard errors are in parentheses. *indicate statistical significance at the $10 \%$ level. $* *$ indicate statistical significance at the $5 \%$ level. $* * *$ indicate statistical significance at the $1 \%$ level. Right-hand side variables are lagged one quarter.

\begin{tabular}{lcc}
\hline Dependent variable & \multicolumn{2}{c}{$\Delta$ loan } \\
\hline UDF $\left(\omega_{2}\right)$ & -0.00141 & $0.0676^{* * *}$ \\
& $(0.0125)$ & $(0.00362)$ \\
OBFLR $\left(\omega_{3}\right)$ & $-0.0329^{*}$ & $-0.0754^{* * *}$ \\
& $(0.0176)$ & $(0.00397)$ \\
UDF*OBFLR $\left(\omega_{4}\right)$ & 0.0621 & $-0.0718^{* * *}$ \\
& $(0.0753)$ & $(0.0181)$ \\
Control variables & yes & yes \\
Time fixed effect & yes & yes \\
Bank fixed effect & yes & yes \\
constant & $0.400^{* * *}$ & $0.347^{* * *}$ \\
& $(0.0410)$ & $(0.0137)$ \\
\hline r2 & 0.204 & 0.186 \\
$\mathrm{~N}$ & 14951 & 329951 \\
\hline
\end{tabular}




\section{APENDIX C: Alternative methodologies of unexpected deposit flows' computation}

This table highlights the conditional impact of unexpected deposit flows on banks' new loan origination using two alternative methodologies of unexpected deposit flows' computation. UDF is the unexpected flow of deposits. In columns (1) and (2), it is measured by the difference between the deposit growth of the small (large) bank $i$ and the growth of the aggregate deposit of small (large) banks. In columns (3) and (4), it is measured by the difference between a bank's deposit growth and the median of deposit growth between banks for each quarter. $\Delta$ loan is the quarterly growth rate of the sum of net loans plus unused commitments. OBFLR is the exposure to off-balance sheet funding liquidity risk. "large" corresponds to banks with total assets higher than $\$ 1$ billion and "small" corresponds to banks with total assets lower or equal to $\$ 1$ billion. Standard errors are in parentheses. *indicate statistical significance at the $10 \%$ level. **indicate statistical significance at the $5 \%$ level. ***indicate statistical significance at the $1 \%$ level. Right-hand side variables are lagged one quarter.

\begin{tabular}{lcccc}
\hline Dependent variable & \multicolumn{3}{c}{$\Delta$ loan } & $(4)$ \\
\hline & $(1)$ & $(2)$ & small \\
\hline Lag dependent variable & large & small & large & $0.00886^{* *}$ \\
& $0.0356^{* *}$ & $0.00877^{* *}$ & $0.0359^{* *}$ & $(0.00376)$ \\
UDF $\left(\omega_{2}\right)$ & $(0.0179)$ & $(0.00376)$ & $(0.0170)$ & $0.0590^{* * *}$ \\
& -0.00105 & $0.0578^{* * *}$ & -0.00670 & $(0.00276)$ \\
OBFLR $\left(\omega_{3}\right)$ & $(0.00878)$ & $(0.00275)$ & $(0.00972)$ & $-0.0762^{* * *}$ \\
& $-0.0417^{* *}$ & $-0.0758^{* * *}$ & $-0.0343^{* *}$ & $(0.00382)$ \\
UDF*OBFLR $\left(\omega_{4}\right)$ & $(0.0180)$ & $(0.00383)$ & $(0.0171)$ & $-0.0565^{* * *}$ \\
& 0.0200 & $-0.0483^{* * *}$ & 0.00701 & $(0.0132)$ \\
Control variables & $(0.0329)$ & $(0.0132)$ & $(0.0331)$ & yes \\
Time fixed effect & yes & yes & yes & yes \\
Bank fixed effect & yes & yes & yes & yes \\
constant & yes & yes & yes & $0.329^{* * *}$ \\
r2 & $0.393^{* * *}$ & $0.330^{* * *}$ & $0.561^{* * *}$ & $(0.0130)$ \\
\hline
\end{tabular}




\section{Appendix D: Unexpected flow of core deposits}

This table highlights the conditional impact of unexpected core deposit flows on banks' new loan origination. $\mathrm{UDF}^{\mathrm{cor}}$ is the unexpected core deposit flows. $\Delta$ coredep is core deposit flows. $\Delta$ loan is the quarterly growth rate of the sum of net loans plus unused commitments. OBFLR is the exposure to off-balance sheet funding liquidity risk. SIZE is the natural logarithm of total assets. LEVERAGE is equity to total assets ratio. NPL is non-performing loans over total loans. CIBD is the cost of interest-bearing deposits. ROE is return on equity. REL is the share of loans secured by real estate in loan portfolio. M\&A is a dummy variable for mergers and acquisitions. It is equal to one if the asset growth rate is lower than $10 \%$ during the quarter and zero otherwise. "large" corresponds to banks with total assets higher than $\$ 1$ billion and "small" corresponds to banks with total assets lower or equal to $\$ 1$ billion. Standard errors are in parentheses. *indicate statistical significance at the $10 \%$ level. **indicate statistical significance at the 5\% level. ***indicate statistical significance at the $1 \%$ level. Right-hand side variables are lagged one quarter.

\begin{tabular}{|c|c|c|c|c|}
\hline \multirow[b]{2}{*}{ Dependent variable } & \multicolumn{2}{|c|}{ large } & \multicolumn{2}{|c|}{ small } \\
\hline & $\Delta$ coredep & $\Delta$ loan & $\Delta$ coredep & $\Delta$ loan \\
\hline \multirow[t]{2}{*}{ Lag dependent variable } & & $0.0310^{*}$ & & $0.0140^{* * *}$ \\
\hline & & $(0.0176)$ & & $(0.00405)$ \\
\hline \multirow[t]{2}{*}{$\mathrm{UDF}^{\mathrm{cor}}\left(\omega_{2}\right)$} & & 0.00953 & & $0.0489^{* * *}$ \\
\hline & & $(0.0129)$ & & $(0.00342)$ \\
\hline \multirow[t]{2}{*}{$\operatorname{OBFLR}\left(\omega_{3}\right)$} & 0.0110 & $-0.0352^{* *}$ & $0.00872^{* * *}$ & $-0.0774^{* * *}$ \\
\hline & $(0.00845)$ & $(0.0175)$ & $(0.00199)$ & $(0.00398)$ \\
\hline \multirow[t]{2}{*}{$\mathrm{UDF}^{\mathrm{cor}} * \mathrm{OBFLR}\left(\omega_{4}\right)$} & & -0.0634 & & $-0.0742^{* * *}$ \\
\hline & & $(0.0811)$ & & $(0.0186)$ \\
\hline \multirow[t]{2}{*}{ SIZE } & $-0.0198^{* * *}$ & $-0.0176^{* * *}$ & $-0.0187^{* * *}$ & $-0.0184^{* * *}$ \\
\hline & $(0.00247)$ & $(0.00190)$ & $(0.000704)$ & $(0.000765)$ \\
\hline \multirow[t]{2}{*}{ LEVERAGE } & 0.0286 & 0.0457 & $0.237^{* * *}$ & $0.146^{* * *}$ \\
\hline & $(0.0275)$ & $(0.0355)$ & $(0.00895)$ & $(0.00911)$ \\
\hline \multirow[t]{2}{*}{ NPL } & $-0.100^{* * *}$ & $-0.357^{* * *}$ & $-0.222^{* * *}$ & $-0.332^{* * *}$ \\
\hline & $(0.0321)$ & $(0.0551)$ & $(0.00719)$ & $(0.00856)$ \\
\hline \multirow[t]{2}{*}{ CIBD } & 0.0228 & & $0.768^{* * *}$ & \\
\hline & $(0.0762)$ & & $(0.0347)$ & \\
\hline \multirow[t]{2}{*}{ ROE } & 0.00229 & 0.00919 & $-0.00319^{* *}$ & $0.00416^{* * *}$ \\
\hline & $(0.00443)$ & $(0.00575)$ & $(0.00131)$ & $(0.00140)$ \\
\hline \multirow[t]{2}{*}{ REL } & -0.00918 & -0.00637 & -0.000476 & $0.00294^{*}$ \\
\hline & $(0.00651)$ & $(0.00721)$ & $(0.00145)$ & $(0.00162)$ \\
\hline \multirow[t]{2}{*}{ M\&A } & 0.00171 & -0.000367 & 0.000496 & $-0.0113^{* * *}$ \\
\hline & $(0.00116)$ & $(0.00159)$ & $(0.000645)$ & $(0.000555)$ \\
\hline Time fixed effect & yes & yes & yes & yes \\
\hline Bank fixed effect & yes & yes & yes & yes \\
\hline \multirow[t]{2}{*}{ constant } & $0.429^{* * *}$ & $0.397^{* * *}$ & $0.269^{* * *}$ & $0.342^{* * *}$ \\
\hline & $(0.0534)$ & $(0.0409)$ & $(0.0123)$ & $(0.0137)$ \\
\hline $\mathrm{r} 2$ & 0.176 & 0.204 & 0.200 & 0.184 \\
\hline $\mathrm{N}$ & 16542 & 14840 & 368204 & 328495 \\
\hline
\end{tabular}




\section{Appendix E: "Traditional" banks}

This table highlights the conditional impact of unexpected deposit flows on banks' new loan origination of "traditional" banks. Those banks are the ones with total deposits to total assets ratio and total loans over total assets higher than $30 \%$. $\Delta$ loan is the quarterly growth rate of the sum of net loans plus unused commitments. UDF is the unexpected deposit flows. OBFLR is the exposure to off-balance sheet funding liquidity risk. "large" corresponds to banks with total assets higher than $\$ 1$ billion and "small" corresponds to banks with total assets lower or equal to $\$ 1$ billion. Standard errors are in parentheses. *indicate statistical significance at the $10 \%$ level. **indicate statistical significance at the 5\% level. ***indicate statistical significance at the $1 \%$ level. Right-hand side variables are lagged one quarter.

\begin{tabular}{lcc}
\hline Dependent variable & \multicolumn{2}{c}{$\Delta$ loan } \\
\hline Lag dependent variable & $0.0342^{*}$ & $0.0129^{* * *}$ \\
& $(0.0181)$ & $(0.00408)$ \\
UDF $\left(\omega_{2}\right)$ & -0.00719 & $0.0666^{* * *}$ \\
& $(0.0130)$ & $(0.00369)$ \\
OBFLR $\left(\omega_{3}\right)$ & $-0.0357^{* *}$ & $-0.0793^{* * *}$ \\
& $(0.0165)$ & $(0.00397)$ \\
UDF*OBFLR $\left(\omega_{4}\right)$ & 0.0775 & $-0.0668^{* * *}$ \\
& $(0.0734)$ & $(0.0188)$ \\
Control variables & yes & yes \\
Time fixed effect & yes & yes \\
Bank fixed effect & yes & yes \\
constant & $0.412^{* * *}$ & $0.373^{* * *}$ \\
& $(0.0451)$ & $(0.0131)$ \\
\hline r2 & 0.210 & 0.191 \\
$\mathrm{~N}$ & 14363 & 315039 \\
\hline
\end{tabular}


Table 1F: Unexpected flow of deposits captured using macroeconomic variables

This table highlights the conditional impact of unexpected deposit flows on banks' new loan origination. UDF is the unexpected deposit flows. It is captured from equation (1) by using macroeconomic factors. $\Delta$ dep is deposit flows. $\Delta$ loan is the quarterly growth rate of the sum of net loans plus unused commitments. OBFLR is the exposure to off-balance sheet funding liquidity risk. SIZE is the natural logarithm of total assets. LEVERAGE is equity to total assets ratio. NPL is non-performing loans over total loans. CIBD is the cost of interest-bearing deposits. ROE is return on equity. REL is the share of loans secured by real estate in loan portfolio. M\&A is a dummy variable for mergers and acquisitions. It is equal to one if the asset growth rate is lower than $10 \%$ during the quarter and zero otherwise. TED spread is the difference between the three-month LIBOR and the three-month T-bill interest rates and INF is change in consumer price index. "large" corresponds to banks with total assets higher than $\$ 1$ billion and "small" corresponds to banks with total assets lower or equal to $\$ 1$ billion. Standard errors are in parentheses. $*$ indicate statistical significance at the $10 \%$ level. $* *$ indicate statistical significance at the $5 \%$ level. ***indicate statistical significance at the $1 \%$ level. Right-hand side variables are lagged one quarter.

\begin{tabular}{|c|c|c|c|c|}
\hline & \multicolumn{2}{|c|}{ large } & \multicolumn{2}{|c|}{ small } \\
\hline Dependent variable & $\Delta$ dep & $\Delta$ loan & $\Delta$ dep & $\Delta$ loan \\
\hline \multirow[t]{2}{*}{ Lag dependent variable } & & $0.0326^{*}$ & & $0.0115^{* * *}$ \\
\hline & & $(0.0176)$ & & $(0.00401)$ \\
\hline \multirow[t]{2}{*}{$\operatorname{UDF}\left(\omega_{2}\right)$} & & -0.00505 & & $0.0640^{* * *}$ \\
\hline & & $(0.0130)$ & & $(0.00357)$ \\
\hline \multirow[t]{2}{*}{$\operatorname{OBFLR}\left(\omega_{3}\right)$} & 0.0140 & $-0.0352^{* *}$ & $0.0242^{* * *}$ & $-0.0761^{* * *}$ \\
\hline & $(0.0128)$ & $(0.0176)$ & $(0.00212)$ & $(0.00396)$ \\
\hline \multirow{2}{*}{$\operatorname{UDF} * \operatorname{OBFLR}\left(\omega_{4}\right)$} & & 0.0544 & & $-0.0545^{* * *}$ \\
\hline & & $(0.0726)$ & & $(0.0178)$ \\
\hline \multirow[t]{2}{*}{ SIZE } & $-0.0206^{* * *}$ & $-0.0177^{* * *}$ & $-0.0122^{* * *}$ & $-0.0184^{* * *}$ \\
\hline & $(0.00220)$ & $(0.00189)$ & $(0.000555)$ & $(0.000761)$ \\
\hline \multirow[t]{2}{*}{ LEVERAGE } & $0.119^{* * *}$ & 0.0469 & $0.327^{* * *}$ & $0.160^{* * *}$ \\
\hline & $(0.0330)$ & $(0.0358)$ & $(0.0101)$ & $(0.00918)$ \\
\hline \multirow[t]{2}{*}{ NPL } & $-0.144^{* * *}$ & $-0.359^{* * *}$ & $-0.256^{* * *}$ & $-0.332^{* * *}$ \\
\hline & $(0.0312)$ & $(0.0549)$ & $(0.00773)$ & $(0.00846)$ \\
\hline \multirow[t]{2}{*}{ CIBD } & $-0.122^{* * *}$ & & $0.130^{* * *}$ & \\
\hline & $(0.0452)$ & & $(0.0117)$ & \\
\hline \multirow[t]{2}{*}{ ROE } & 0.00773 & 0.00915 & -0.0000684 & $0.00391^{* * *}$ \\
\hline & $(0.00570)$ & $(0.00570)$ & $(0.00138)$ & $(0.00139)$ \\
\hline \multirow[t]{2}{*}{ REL } & -0.00607 & -0.00615 & $0.0101^{* * *}$ & $0.00352^{* *}$ \\
\hline & $(0.00714)$ & $(0.00723)$ & $(0.00163)$ & $(0.00161)$ \\
\hline \multirow[t]{2}{*}{ M\&A } & 0.00171 & -0.000655 & $-0.00233^{* * *}$ & $-0.00873^{* * *}$ \\
\hline & $(0.00144)$ & $(0.00163)$ & $(0.000718)$ & $(0.000564)$ \\
\hline \multirow[t]{2}{*}{ TED spread } & $0.673^{* * *}$ & & $0.203^{* * *}$ & \\
\hline & $(0.121)$ & & $(0.0333)$ & \\
\hline \multirow[t]{2}{*}{ INF } & 0.000415 & & $0.000423^{* * *}$ & \\
\hline & $(0.000390)$ & & $(0.0000962)$ & \\
\hline \multirow[t]{2}{*}{ constant } & $0.453^{* * *}$ & $0.399^{* * *}$ & $0.194^{* * *}$ & $0.338^{* * *}$ \\
\hline & $(0.0486)$ & $(0.0407)$ & $(0.0101)$ & $(0.0136)$ \\
\hline $\mathrm{r} 2$ & 0.167 & 0.204 & 0.173 & 0.186 \\
\hline $\mathrm{N}$ & 16821 & 14951 & 372085 & 329951 \\
\hline
\end{tabular}




\section{Table 2F: Control of macroeconomic effects with GDP}

This table highlights the conditional impact of unexpected deposit flows on banks' new loan origination. In equation (3), we replace time dummies by the growth rate of GDP per capita (rgdpc). UDF is the unexpected deposit flows. $\Delta$ dep is deposit flows. $\Delta$ loan is the quarterly growth rate of the sum of net loans plus unused commitments. OBFLR is the exposure to off-balance sheet funding liquidity risk. SIZE is the natural logarithm of total assets. LEVERAGE is equity to total assets ratio. NPL is non-performing loans over total loans. REL is the share of loans secured by real estate in loan portfolio. M\&A is a dummy variable for mergers and acquisitions. It is equal to one if the asset growth rate is lower than $10 \%$ during the quarter and zero otherwise. "large" corresponds to banks with total assets higher than $\$ 1$ billion and "small" corresponds to banks with total assets lower or equal to $\$ 1$ billion. Standard errors are in parentheses. *indicate statistical significance at the $10 \%$ level. **indicate statistical significance at the 5\% level. ***indicate statistical significance at the $1 \%$ level. Right-hand side variables are lagged one quarter.

\begin{tabular}{|c|c|c|}
\hline \multirow[t]{2}{*}{ Dependent variable } & \multicolumn{2}{|c|}{$\Delta$ loan } \\
\hline & large & small \\
\hline \multirow[t]{2}{*}{ Lag dependent variable } & $0.0403^{* *}$ & $0.0119^{* * *}$ \\
\hline & $(0.0177)$ & $(0.00404)$ \\
\hline \multirow[t]{2}{*}{$\operatorname{UDF}\left(\omega_{2}\right)$} & -0.00935 & $0.0605^{* * *}$ \\
\hline & $(0.0129)$ & $(0.00362)$ \\
\hline \multirow[t]{2}{*}{$\operatorname{OBFLR}\left(\omega_{3}\right)$} & $-0.0272^{*}$ & $-0.0533^{* * *}$ \\
\hline & $(0.0154)$ & $(0.00314)$ \\
\hline \multirow[t]{2}{*}{$\mathrm{UDF}^{*} \operatorname{OBFLR}\left(\omega_{4}\right)$} & 0.0659 & $-0.0662^{* * *}$ \\
\hline & $(0.0759)$ & $(0.0180)$ \\
\hline \multirow[t]{2}{*}{ SIZE } & $-0.0129^{* * *}$ & $-0.0103^{* * *}$ \\
\hline & $(0.00123)$ & $(0.000409)$ \\
\hline \multirow[t]{2}{*}{ LEVERAGE } & $0.0922^{* *}$ & $0.198^{* * *}$ \\
\hline & $(0.0367)$ & $(0.00885)$ \\
\hline \multirow[t]{2}{*}{ NPL } & $-0.425^{* * *}$ & $-0.383^{* * *}$ \\
\hline & $(0.0459)$ & $(0.00810)$ \\
\hline \multirow[t]{2}{*}{ ROE } & $0.0164^{* * *}$ & $0.00745^{* * *}$ \\
\hline & $(0.00576)$ & $(0.00138)$ \\
\hline \multirow[t]{2}{*}{ REL } & 0.000535 & $0.0145^{* * *}$ \\
\hline & $(0.00641)$ & $(0.00154)$ \\
\hline \multirow[t]{2}{*}{ M\&A } & 0.00102 & $-0.00921^{* * *}$ \\
\hline & $(0.00166)$ & $(0.000566)$ \\
\hline \multirow[t]{2}{*}{ rgdpc } & $0.253^{* * *}$ & $0.233^{* * *}$ \\
\hline & $(0.0686)$ & $(0.0143)$ \\
\hline \multirow[t]{2}{*}{ constant } & $0.295^{* * *}$ & $0.192^{* * *}$ \\
\hline & $(0.0263)$ & $(0.00713)$ \\
\hline $\mathrm{r} 2$ & 0.181 & 0.168 \\
\hline $\mathrm{N}$ & 14951 & 329951 \\
\hline
\end{tabular}




\section{Appendix G:}

This table highlights the conditional impact of unexpected deposit flows on banks' new loan origination using a sample without bank-quarter observations with quarterly asset growth higher than $10 \%$. UDF is the unexpected deposit flows. $\Delta$ dep is deposit flows. $\Delta$ loan is the quarterly growth rate of the sum of net loans plus unused commitments. OBFLR is the exposure to off-balance sheet funding liquidity risk. SIZE is the natural logarithm of total assets. LEVERAGE is equity to total assets ratio. NPL is non-performing loans over total loans. CIBD is the cost of interest-bearing deposits. ROE is return on equity. REL is the share of loans secured by real estate in loan portfolio. "large" corresponds to banks with total assets higher than $\$ 1$ billion and "small" corresponds to banks with total assets lower or equal to $\$ 1$ billion. Standard errors are in parentheses. *indicate statistical significance at the $10 \%$ level. $* *$ indicate statistical significance at the $5 \%$ level. $* * *$ indicate statistical significance at the $1 \%$ level. Right-hand side variables are lagged one quarter.

\begin{tabular}{|c|c|c|c|c|}
\hline \multirow[b]{2}{*}{ Dependent variable } & \multicolumn{2}{|c|}{ large } & \multicolumn{2}{|c|}{ small } \\
\hline & $\Delta$ dep & $\Delta$ loan & $\Delta$ dep & $\Delta$ loan \\
\hline \multirow[t]{2}{*}{ Lag dependent variable } & & $0.0628^{* * *}$ & & $-0.0290^{* * *}$ \\
\hline & & $(0.0210)$ & & $(0.00398)$ \\
\hline \multirow[t]{2}{*}{$\operatorname{UDF}\left(\omega_{2}\right)$} & & 0.00178 & & $0.0513^{* * *}$ \\
\hline & & $(0.0130)$ & & $(0.00360)$ \\
\hline \multirow[t]{2}{*}{$\operatorname{OBFLR}\left(\omega_{3}\right)$} & 0.00573 & $-0.0516^{* * *}$ & $0.00599^{* * *}$ & $-0.0715^{* * *}$ \\
\hline & $(0.00818)$ & $(0.0170)$ & $(0.00145)$ & $(0.00375)$ \\
\hline \multirow{2}{*}{$\mathrm{UDF}^{*} \mathrm{OBFLR}\left(\omega_{4}\right)$} & & 0.134 & & $-0.0587^{* *}$ \\
\hline & & $(0.0977)$ & & $(0.0237)$ \\
\hline \multirow[t]{2}{*}{ SIZE } & $-0.00577^{* * *}$ & $-0.00433^{* * *}$ & $-0.00881^{* * *}$ & $-0.0107^{* * *}$ \\
\hline & $(0.00142)$ & $(0.00133)$ & $(0.000489)$ & $(0.000565)$ \\
\hline \multirow[t]{2}{*}{ LEVERAGE } & $0.0559^{* * *}$ & 0.0342 & $0.133^{* * *}$ & $0.0303^{* * *}$ \\
\hline & $(0.0212)$ & $(0.0257)$ & $(0.00677)$ & $(0.00740)$ \\
\hline \multirow[t]{2}{*}{ NPL } & $-0.146^{* * *}$ & $-0.327^{* * *}$ & $-0.213^{* * *}$ & $-0.291^{* * *}$ \\
\hline & $(0.0245)$ & $(0.0417)$ & $(0.00580)$ & $(0.00791)$ \\
\hline \multirow[t]{2}{*}{ CIBD } & -0.0735 & & $0.525^{* * *}$ & \\
\hline & $(0.0610)$ & & $(0.0271)$ & \\
\hline \multirow[t]{2}{*}{ ROE } & $0.00807^{* *}$ & $0.0132^{* * *}$ & $0.00987^{* * *}$ & $0.00832^{* * *}$ \\
\hline & $(0.00402)$ & $(0.00457)$ & $(0.00102)$ & $(0.00126)$ \\
\hline \multirow[t]{2}{*}{ REL } & $-0.00852^{* *}$ & -0.00608 & 0.000388 & 0.00142 \\
\hline & $(0.00409)$ & $(0.00585)$ & $(0.00106)$ & $(0.00142)$ \\
\hline Time fixed effect & yes & yes & yes & yes \\
\hline Bank fixed effect & yes & yes & yes & yes \\
\hline \multirow[t]{2}{*}{ constant } & $0.140^{* * *}$ & $0.109^{* * *}$ & $0.116^{* * *}$ & $0.203^{* * *}$ \\
\hline & $(0.0297)$ & $(0.0285)$ & $(0.00847)$ & $(0.0101)$ \\
\hline r2 & 0.123 & 0.259 & 0.141 & 0.140 \\
\hline $\mathrm{N}$ & 14967 & 12338 & 349621 & 295460 \\
\hline
\end{tabular}


Appendix H: Effect of unexpected deposit flows on small banks loan production at different levels of the exposure to off-balance sheet funding liquidity risk

This table shows the marginal effects of unexpected deposit flows on small banks' new loans. To compute these marginal effects, we regress the following equation:

$\Delta \operatorname{loan}_{i . t}=\gamma_{i}+\theta_{t}+\omega_{1} U D F_{i . t-1}+\omega_{2} O B F L R_{i . t-1}+\omega_{3} U D F_{i . t-1} * O B F L R_{i . t-1}+\omega X_{i . t-1}+\mu_{i . t}$

\begin{tabular}{cccc}
\hline unexpected deposit flows at: & $\mathrm{dy} / \mathrm{dx}$ & Std. Err & $\mathrm{p}$ value \\
\hline $10^{\text {th }}$ percentile of OBFLR & 0.0673762 & 0.0035976 & 0.000 \\
$25^{\text {th }}$ percentile of OBFLR & 0.0662861 & 0.0034657 & 0.000 \\
$50^{\text {th }}$ percentile of OBFLR & 0.063349 & 0.0032027 & 0.000 \\
$75^{\text {th }}$ percentile of OBFLR & 0.0575171 & 0.0031686 & 0.000 \\
$90^{\text {th }}$ percentile of OBFLR & 0.0441359 & 0.0050949 & 0.000 \\
\hline
\end{tabular}

